Cornell Law Library

Scholarship@Cornell Law: A Digital Repository

Cornell Law Faculty Publications

Faculty Scholarship

$10-1-2010$

\title{
Migrant Domestic Workers in Egypt: A Case Study of the Economic Family in Global Context
}

Chantal Thomas

Cornell Law School, chantal-thomas@lawschool.cornell.edu

Follow this and additional works at: http://scholarship.law.cornell.edu/facpub

Part of the Comparative and Foreign Law Commons, and the International Law Commons

\section{Recommended Citation}

Thomas, Chantal, "Migrant Domestic Workers in Egypt: A Case Study of the Economic Family in Global Context" (2010). Cornell Law Faculty Publications. Paper 610.

http://scholarship.law.cornell.edu/facpub/610

This Article is brought to you for free and open access by the Faculty Scholarship at Scholarship@Cornell Law: A Digital Repository. It has been accepted for inclusion in Cornell Law Faculty Publications by an authorized administrator of Scholarship@Cornell Law: A Digital Repository. For more information, please contact jmp8@cornell.edu. 


\section{Migrant Domestic Workers in Egypt: A Case Study of the Economic Family in Global Context $\dagger$}

This Essay links a particular legal case study with a broader set of questions about the "family" in a global political and economic context. Part I clarifies the analytic links between the household, the market, and globalization. By studying Egypt, the Essay focuses on one part of this global sociolegal continuum and draws out the special significance of transnational background rules and conditions for the "developmental state." Part II presents the legal framework affecting labor conditions of sub-Saharan African asylum-seekers who are migrant domestic workers in Egypt, and particularly the legal framework that affects their ability to bargain in securing livelihood strategies. Domestic and international law fail to provide adequate assistance and support for these efforts, but they inevitably construct the

* Professor of Law, Cornell Law School. I am grateful to Cornell Law School for its generous support of research conducted for this Essay in the spring of 2009. Scholars based at the American University in Cairo Center for Migration and Refugee Studies and its Department of Law-in particular Philippe Fargues, Ray Jureidini, Michael Kagan, and Mulki Sharmani-provided essential access, information, and advice. Inspiration has also come from the following interventions: Lama Abu-Odeh, Panel on "Sex, Gender and International Law," American Society of International Law Annual Meeting (Mar. 31, 2006); Adelle Blackett, Making Domestic Work Visible: The Case for Specific Regulation (ILO Labor Law and Labor Relations Programme, Working Paper No. 2, 1998); Hani Sayed, The Post-Developmental State (2009) (manuscript on file with author); Adelle Blackett's establishment of the Labor Law and Development Research Network (LLDRN), as well as from conversations with the other members of the LLDRN, Dzodzi Tzikata, Diamond Ashiagbor, and Rose-Marie Belle-Antoine; Prabha Kotiswaran, Wives and Whores: The Regulation of the Economies in Sexual Labour, in Redefining Family Law in India: Essays in Honour of B. SrvaramayYa (Archana Parashar \& Amita Dhanda eds., 2007); Guy Mundlak \& Hila Shamir, Between Intimacy and Alienage: the Legal Construction of Domestic \& Care Work in the Welfare State, in Migration and Domestic Work: A European Perspective ON A Global Theme 161-76 (Helma Lutz ed., 2008); Kerry Rittich, Recharacterizing Restructuring (2002); Kerry Rittich, Rights, Risk and Reward: Governance Norms in the International Order and the Problem of Precarious Work, in Precarious Work, Women, and the New Economy: The Challenge to Legal Norms 31 (Judy Fudge \& Rosemary Owens eds., 2006); Philomila Tsoukala, Gary Becker, Legal Feminism, and the Costs of Moralizing Care, 16 Colum. J. GENDER \& L. 357 (2007); and the "Up Against Family Law Exceptionalism" (UAFLE) meetings organized by Brenda Cossman, Janet Halley, and Kerry Rittich. Sincere thanks to all of these interlocutors. Errors are mine alone. This paper incorporates remarks that I prepared for the Radcliffe Institute for Advanced Study conference, March 2009, on "Gender and the Law: Unintended Consequences, Unsettling Questions."

$\dagger$ DOI 10.5131/ajcl.2010.0009. 
environments for them: "foreground" rules of employment and contract law (but not family law) affect the bargaining environment for migrant domestic workers; "background" rules, most importantly those related to sovereignty and immigration, also crucially influence the bargaining environment. Part III returns to the conceptual landscape, connecting this study with current quandaries in global governance studies and critical understandings of the "economic family."

\section{INTRODUCTION}

Although the domestic worker is part of the "economic family," supplying necessary labor to the household, the paradigm of family law does not govern the terms and conditions of domestic work. Family law concerns itself primarily with marital and parental relationships; as a consequence, it tends to conceptualize women in households as wives and mothers. For the same reason, issues of waged work and employment arise in family law primarily as they affect marital and parental relationships (e.g., through the valuations relevant to divorce proceedings). The "household" and the "family" are contiguous domains of unwaged work, largely distinct from the waged-labor marketplace.

Domestic workers destabilize such demarcations of the household and the market. Without legally recognized familial ties to the households they work for, domestic workers instead relate to these households as employees or independent contractors. Predominantly women, ${ }^{1}$ they provide waged care work supporting households in which they are neither wives nor mothers, for employers who are frequently the household wives and mothers. Market conditions often, though not always, disfavor domestic workers against their employers. $^{2}$

My goal in this Essay is to link a particular legal case study of domestic workers with a global political and economic context. This Essay examines the legal framework affecting the labor environment for African, and particularly Sudanese, asylum-seekers who work as household help in Cairo, Egypt. ${ }^{3}$ A "developmental state" such as

1. International Labour Organization [ILO], Int'l Lab. Conf., 99th Session, June 2-18, 2010, Decent Work for Domestic Workers, at 6, Report IV(1) ("women invariably make up the overwhelming majority of domestic workers") (hereinafter 2010 ILO Report].

2. See infra Part I.A., I.B., and II.C.

3. See infra Part II.A. and II.B. Egypt, an African country that is also often considered to be part of the Middle East, draws asylum seekers from both regions. Though many asylum seekers in Egypt also come from other countries in the Arab world, those from Sudan, the Horn of Africa (Eritrea, Ethiopia, Somalia) and subSaharan Africa (most proximately Chad, Uganda, and the Democratic Republic of Congo, but also including nationals of western and southern African countries) are far 
Egypt represents an important part of the global sociolegal continuum for labor migration and ultimately for migrant domestic workers. One of the aspirations of this paper is to demonstrate that the phenomenon of irregular migration to a developing country such as Egypt is intimately interconnected with broader effects of modernity and globalization. This focus resists the conventional notion of the modern household as economically residual. The household is an economically significant site, linked to patterns of globalization. ${ }^{4}$

The overwhelming livelihood strategy of these asylum seekers situates them as "irregular" (undocumented) migrant domestic workers. In understanding how law affects these livelihood strategies, this Essay does not look to family law as traditionally defined but rather to the laws which shape the work environment: first, to legal exceptionalism in "foreground" rules of employment and contract affecting domestic workers, and, second, to "background" rules and conditions governing migration and development that that link national economies through global dynamics and that contribute to sociolegal environments of "informality" and "irregularity" for domestic workers. These legal rules and institutions governing employment and immigration are not the domain of family law, conventionally understood. Nevertheless, they importantly shape the conditions in which family law relationships arise.

Methodologically, this exposition combines core insights of legal realism-from $\mathrm{Hale}^{5}$ to Hohfeld ${ }^{6}$-with tools from governance studies in economics, critical theory and political science that look not only to formal laws stemming from state actors, but also to other potentially regulatory actors and forces: less explicit state practices of implementation and administration, non-state actors (international and non-governmental organizations), ideologies and informal norms, and economic relationships. ${ }^{7}$ Proper analysis of the laws must in-

more visible and much less well assimilated. United Nations High Commissioner for Refugees [UNHCR], 2005 STAT. Y.B. 319 (showing that recognized refugees from the Occupied Palestinian Territories far outnumber recognized refugees from the Sudan or any other African country. More recently, huge waves of Iraqis have fled to Egypt and elsewhere). See UNHCR, RESETTLEMENT OF IRAQI REFUgEES (2007).

4. See Janet Halley \& Kerry Rittich, Critical Directions in Comparative Family Law, 58 Aм. J. Comp. L. 753 (2010), for an exposition on the relationship of this proposition to world-systems theory.

5. See, e.g., infra text and note 20.

6. See, e.g., infra text and note 124 .

7. In the study of governance we see a convergence of analytical methods from different parts of the academy: economists such as Douglass North have offered institutional analysis which includes both formal rules and informal norms and ideologies, as well as methods of implementation and enforcement (or lack thereof) by the state and the impact of economic and social forces, see, e.g., Douglass C. NoRTH, INSTITUtions, Institutional Change and Economic Performance (1990). Critical theorists such as Michel Foucault have adopted studies of governmentality which pay close attention both to administrative practices of the state and to forms of knowledge that shape power relations within state and social structures, see, e.g., Michel Foucault, 
clude their application through formal channels of doctrinal interpretation and implementation within the relevant institution (the state or the international organization in this context), the background social context, and the economic environment. This interdisciplinary method more accurately measures legal and institutional effect.

\section{General Causes of Legal Informality Affecting Migrant DOMESTIC WORKERS}

Informality is legally produced through multiple layers of permission, omission, and prohibition. The informal labor environment for migrant domestic workers is importantly constructed by law in both its explicit content and in its application. In order to lay the groundwork for Part II's close study of the legal framework for asylum-seekers as migrant domestic workers in Egypt, this section sets out three general sources of legal informality for migrant domestic workers that arise at different levels: legal exceptionalism for domestic work; irregularity in migration; and the economics of the developmental state.

\section{A. Informality from Legal Exceptionalism for Domestic Work}

According to comparative studies of national legal systems, exceptional legal status for domestic workers manifests itself in a range of ways. ${ }^{8}$ Egypt is one of many legal systems that contain outright exclusions of domestic workers from labor codes and other regulations. ${ }^{9}$ This characteristic exclusion from legal regulation ${ }^{10}$

SuRveILLIR ET PUNIR (1975). Both approaches influence the analysis here. Additionally, the study of "global governance" by political scientists in international relations has offered the key precept that regulatory effects stem from both state and non-state actors. See, e.g., Governance in a Globalizing World (Joseph S. Nye \& John D. Donahue eds., 2000),

8. Extensive comparative analyses of national legal systems have been conducted by the ILO. See, e.g., José M. Ramirez-Machado, Domestic Work, Conditions of Work and Employment: A Legal Perspective, ILO Conditions of Work and Employment Series No. 7 (2003) [hereinafter 2003 ILO Report]; 2010 ILO Report, supra note 1. Such comparison, needless to say, requires multiple disclaimers, as it is challenged not only by differences in legal contexts but also by the fact that labor protections can arise from multiple formal and institutional sources within any given country.

9. 2003 ILO Report, supra note 8, at 7 ("Quite frequently, labour laws refer to domestic workers either to exclude them completely from their scope or to grant them lower levels of protection by being deprived on many of the rights accorded to other categories of workers."). This arrangement characterizes between twenty and twentyfive percent of studied countries. Compare 2003 ILO Report, supra note 8, at 9 (finding that nine of sixty-four countries explicitly excluded domestic workers from labor laws), with 2010 ILO Report, supra note 1, Appendix (listing about twenty-five percent out of a total of seventy-two countries with explicit exclusions).

10. In a second group of legal systems, domestic workers are not explicitly excluded, but are not explicitly mentioned either, creating questions about the applicability of the general laws. Compare 2003 ILO Report, supra note 8, at 8 (finding that seventeen of sixty-four countries "have set no specific regulations on domestic 
work in their basic labour legislation"), with 2010 ILO Report, supra note 1 (finding about half of seventy-two countries do not specifically address domestic workers). Whereas the 2003 ILO report draws no conclusions about the applicability of labor laws to domestic workers in such cases, the 2010 report reflects efforts by the ILO to take a broad perspective, stating that "this report ... has, along with the [ILO's Committee of Experts on the Application of Conventions and Recommendations] the ILO's Legal Adviser, made the assumption that unless domestic workers are explicitly excluded from the scope of labour legislation they are included." 2010 ILO Report, supra note 1 , at 26 , para. 88 . The third group of legal systems, in which domestic workers are explicitly addressed, establishes separate standards for domestic workers, either in discrete sections of the general labor code or in entirely different regulations. Compare 2003 ILO Report, supra note 8 (finding thirty-eight of sixty-four countries' labor laws addressed domestic workers in separate regulations), with 2010 ILO Report, supra note 1 (finding about twenty-five percent of countries explicitly addressed domestic workers in separate regulations). Such provisions nevertheless typically create less than complete parity with other types of work. See, e.g., 2010 ILO Report, supra note 1 , at 49, Figure IV.1 ("As can be seen from figure IV.1, there are significant differences between generally applicable working time standards and those that concern domestic workers. Globally, domestic workers are usually subject to less protective limits than those applied to the general workforce. Half of the countries surveyed permit the domestic labour force to work longer hours than other workers, while just over forty-five percent of countries impose the same limit for all workers; a small percentage have a lower limit or no limit at all for domestic workers.").

Successful mobilization by labor, human rights, and other social movements have brought about some new initiatives to include or expand provisions on domestic work. See 2010 ILO Report, supra note 1, at 23-24 (describing initiatives in Spain, Uruguay, South Africa, and India). "Despite this, and despite its nominal inclusion in legislation, paid domestic work remains virtually invisible as a form of employment in many countries." 2010 ILO Report, supra note 1, at 12, para. 44. In the United States, for example, both federal and state labor laws reflect the exceptional, and often excluded, status of domestic workers. Federal labor statutes amended a previous exclusion for some domestic workers from minimum wage and maximum hours restrictions in 1974, but still exclude "companions" for the sick or elderly. 29 U.S.C. $\S 213(\mathrm{a})(15)(2006)$. Federal statutory protections for the right to organize explicitly exclude all domestic workers. National Labor Relations Act, 29 U.S.C. $§ 152(3)(2006)$. Occupational health and safety standards do not exclude domestic workers at the statutory level, but that exclusion was nevertheless adopted at the administrative agency level "as a matter of policy." 29 C.F.R. \$ 1975.6 (2006). Federal antidiscrimination provisions, though they contain no explicit exclusion of domestic workers, operate to exclude them in practice since they apply only to workplaces of fifteen or more employees. 42 U.S.C. \& $2000 \mathrm{e}(\mathrm{b})$ (2006). State laws in the United States are, of course, more various, but reflect similar patchworks of exclusion and differential treatment. As one example, in the state of New York, the minimum wage and hours laws apply to all workers (though not explicitly mentioning domestic workers). New York Minimum Wage Act, N.Y. Lab. Law $\S \S 650-665$ (Consol. 2010). Most other New York state labor laws either explicitly exclude domestic work, New York State Labor Relations Act, N.Y. Lab. Law $\S 701(3)$ (a) (Consol. 2010), fail to explicitly include it among a list of other specified occupations, N.Y. Lab. Law $\S 161$ (Consol. 2010) (establishing one day of rest for a series of employees of owners of "dwellings" and other residences, but making no reference in the series to domestic workers), or include it but provide a lesser level of regulation. As in federal law, New York state labor law excludes live-in domestic workers from standard overtime rules, though unlike federal law New York does guarantee a lower level of overtime for them. N.Y. ComP. CoDES R. \& REGS. tit.12, \& 142-2.2 (2010). Legislation has recently been proposed to amend this exceptionalism, and in the process has touched on central questions relating to the propriety of and justifications for it. See, e.g., Mona Simpson, Pay Your Nanny on the Books, N.Y. Times (July 2, 2010), at A21 (describing the bill, passed by the New York state legislature and pending signature and approval by New York's governor, which would bring domestic workers into line with standard protections on overtime, sick leave, and vacation). In conclusion, though the U.S. system of federalism creates a 
contributes to an economic environment of pronounced informality, in which market transactions are not actively monitored or regulated by the government and without clearly defined contracts or protections. ${ }^{11}$

The movement of the domestic worker out of the realm of the household represents one aspect of the broader move from "status to contract,"12 against a backdrop in which industrialization shifted the bulk of production from "traditional" household-centered agrarianism to "modern" production occurring in firms. ${ }^{13}$ Yet that legal transformation has been far from complete.

A number of policy justifications exist for the lack of domestic work regulation. They include challenges to administrability posed by the small scale of domestic work and the "specificity"14 of domestic work conditions. The personal or intimate nature of the relationship between domestic workers and the families for which they work also heavily informs resistance to regulation. ${ }^{15}$ As the saying goes, domestic workers are "just like one of the family," 16 triggering conceptual resistance to formal legal intervention in the family private sphere. Next to such ostensibly more neutral reasons, however, lie conscious or unconscious legacies of slavery and servitude. ${ }^{17}$

\section{B. Informality from Irregular Migration}

Domestic work is also increasingly characterized by the "prevalence of migrant work."18

more convoluted regulatory structure, in essential aspects it mirrors the pattern of legal exceptionalism discussed in the text.

11. For extensive discussion of the concept of economic informality, see generally Linking the Formal and Informal Economy: Concepts and Policies (Basudeb Guha-Khasnobis et al. eds., 2006).

12. Harry Sumner Maine, Ancient Law 100 (1861) ("we may say that the movement of the progressive societies has hitherto been a movement from Status to Contract"); see also Duncan Kennedy, The Rise and Fall of Classical Legal THOUGHT ch. 4 (1975). In eighteenth century legal treatises, the household included not only marital (husband-wife) and parental (parent-child) relations, but also those of "master and servant." See Janet Halley, Family Law in America: A Genealogy 4 (2009). In the nineteenth century, the household servant became a paid wage laborer and that legal relationship became defined by contract.

13. See Halley, supra note 12.

14. 2003 ILO Report, supra note 8, at 8; 2010 ILO Report, supra note 1, at 24 . See infra Part II.B.4.(discussing ILO justifications for not including domestic work in international labor standards).

15. See Mundlak \& Shamir, supra note *.

16. See Bridget Anderson, Doing the Dirty Work: The Global Politics of Domestic LaBour ch. 9 (2000).

17. See id., at 126; David Bacon, Illegal People: How Globalization Creates Migration and Criminalizes Immigrants (2008); see also infra Part III.B.

18. 2010 ILO Report, supra note 1 , at 21 ("One of the most striking changes in domestic work in the past 30 years has been the growing prevalence of migrant work."). 
Though most migrants are authorized to enter their countries of destination, migrants also enter without proper documentary status. In traditional conceptions-and under current legal frameworksundocumented migrants have been divided into distinct categories. "Forced" migration refers to those who arrive in a foreign country without proper documentation because they have been compelled by political persecution, and who now seek asylum. If successful, these asylum seekers will be recognized as refugees and will be resettled. By contrast, labor migration refers to those who leave home for "merely" economic reasons. In application, however, it is hard to keep these categories distinct. Migration experts are increasingly challenging this dichotomy as it applies to undocumented migrants. These experts argue instead for a single term of "irregular" migration, which would group both categories together or at least place them on a continuum with each other. ${ }^{19}$

Forced and labor migration have interconnected causes in the country of origin. Rather than distinct phenomena, political persecution and economic desperation may be co-effects of the same problematic environment in which political and economic instability and inequality feed into each other. Though rooted in legal tradition, the view that economic circumstances are not coercive is a particular and limited one. ${ }^{20}$

The interconnection between "forced" and "economic" migration also characterizes the experiences of migrants in the host country. The relative ease of access to asylum procedures stems from the conception of undocumented migration as a crime, ${ }^{21}$ which may therefore be more easily excused than justified. Refugee status, though difficult to obtain, may be easier to claim than regular work authorization. ${ }^{22}$ In addition, once in the new country, both political

19. Philippe Fargues, Work, Refuge, Transit: An Emerging Pattern of Irregular Immigration South and East of the Mediterranean, CARIM Analytic and Synthetic Notes 2009/02, Irregular Migration Series, Background Paper (" $[T]$ hese . . . categories are not as distinct as one might think in terms of migration motives."). Fargues adds the third category of "transit" migrants, or those seeking to migrate elsewhere either through the refugee resettlement process or for work. This category is quite important in Egypt, as will be discussed below, but not necessary for the introductory discussion in this section.

20. Robert L. Hale, Coercion and Distribution in a Supposedly Non-Coercive State, 38 PoL. ScI. Q. 470 (1923).

21. See Fargues, supra note 19.

22. International Organization for Migration [IOM], World Migration Report 2008: Managing Labour Mobility in the Evolving Global Economy 206 (2008) [hereinafter 2008 IOM Report] (describing the "so-called 'nexus' between asylum and migration: the propensity of significant numbers of irregular migrants to make use of asylum procedures not because of a genuine need for protection, but to gain entry to new countries and access to their labor markets. This pattern is particularly evident when asylum systems are perceived as the primary or only official mechanism sanctioning the entry and stay of foreigners in the absence of an alternative means of access to the labor market."); Guy Mundlak, Irregular Migration in Israel-A Legal Perspective, at 1, CARIM Analytic and Synthetic Notes 2008/59, Irregular Migration 
asylum seekers and migrant workers find themselves faced with the same challenges and survival options. ${ }^{23}$ Their experiences and livelihood strategies at that point can become indistinguishable.

The difficulty in access for economic or labor migration contributes to "the development of informal labor markets," ${ }^{4}$ since "the informal economy is the natural point of insertion into the labor force for migrants who cannot find regular employment because of their lack of appropriate documentation." 25 Informality and irregularity tend to occur in low-skilled and less profitable sectors. ${ }^{26}$ For a variety of reasons, migrants, and particularly migrant women, often end up in domestic work. Domestic work lacks licensing and membership requirements that form barriers to entry in other, more highly remunerative occupations that are therefore harder for foreign nationals to join. As one of the least well-paid and least secure types of jobs, it is also the most susceptible to newly arrived and poor workers.

Thus, economic informality both attracts, and is increased by, the presence of irregular migrants. Domestic work, as a major part of the informal economy, thus becomes a major draw for migrant women with "irregular" status seeking livelihoods. ${ }^{27}$

\section{Informality in the Developmental State}

Though the most visible debates about immigration seem to focus on influxes from South to North, in fact most migrants "move from one developing country to another rather than from a developing country to a developed one." 28 If unchecked immigration is viewed as a challenge to sovereignty or statehood, the challenge seems more acute precisely in the postcolonial global South in which sovereignty is comparatively recent and sometimes still contested.

Geographical proximity is of course one reason for the disproportionate migration between developing countries. These countries tend to be easier points of entry for other reasons as well, either intentionally for reasons of political solidarity or due to a lack of administrative and policing border control capacity. Both reasons ap-

Series, Legal Module, at 2 ("Some [migrants] attempt the asylum avenue given the tight control over labor migration.").

23. Fargues, supra note 19 , at 1 (these groups "tend to merge into one category in the local reality ... where [they] have no legal access to labor, welfare and protection, and, at best, subsist.").

24. 2008 IOM Report, supra note 22 , at $43-44$.

25. Id. at 207 .

26. Id. at 206 .

27. Id. at 82 ("Female labor migration is characterized in particular by its concentration in a very limited number of female-dominated (essentially lower-skilled) occupations associated with traditional gender role, such as domestic . . . .); id. at Text Box 3.2 .

28. Id. at 32. See infra Part III.A. for further reflections on migration. 
ply to Egypt: the Egyptian constitution welcomes political asylumseekers, and until recently Egypt's southern borders remained relatively porous. ${ }^{29}$

Economic informality also exerts a particular pull in "the developmental state." ${ }^{30}$ The International Labor Organization reports that in developing countries generally between one-half and threequarters of non-agricultural jobs are informal. Moreover, though once viewed as a vestige of "traditional" economic production that would subside with economic modernization, it is now apparent that economic informality is "actually expanding" in developing countries. ${ }^{31}$ Thus, the issue of economic informality has become the issue of economic "informalization," denoting a process that is dynamically increasing in significance. ${ }^{32}$

This process of economic informalization reflects a number of factors in developing countries: the deregulatory trend in the global economy generally in the past quarter-century; 33 the adoption of neoliberal economic policies under debt arrangements, established by international financial institutions; ${ }^{34}$ and the decay of bureaucratic infrastructure. As a consequence, in many developing countries that once sought to maintain state-managed industrialization, employment in the formal and public sectors (often highly correlative) has now greatly declined..$^{35}$

29. See infra note 40 for a detailed discussion of factors contributing to migration from sub-Saharan Africa to Egypt.

30. For a discussion of "the developmental state," see David M. Trubek, Developmental States and the Legal Order: Towards a New Political Economy of Development and Law, Remarks at the Conference on Social Science in the Age of Globalization National Institute for Advanced Study on Social Science, Fudan University, Shanghai (Dec. 2008), available at http://papers.ssrn.com/sol3/papers.cfm? abstract_id=1349163. There is an emerging body of scholarship on law and development. See, e.g., The New Law and Economic Development: A Critical Appraisal (David M. Trubek \& Alvaro Santos eds., 2006).

31. Martha Alter Chen, Rethinking the Informal Economy: Linkages with the Formal Economy and the Formal Regulatory Environment, in LiNKING THE FORMAL AND INFORMAL ECONOMY, supra note 11, at 75,81 .

32. James Heintz \& Robert Pollin, Informalization, Economic Growth and the Challenge of Creating Viable Labor Standards in Developing Countries 1 (Political Economy Research Institute [PERI], Working Paper No. 60, 2003) ("Over recent decades, conditions for working people in developing countries have undergone a major transformation. This has been the substantial rise in the proportion of people engaged in what is termed 'informal' employment, generating a broad trend toward 'informalization' of labor market conditions in developing countries. Current estimates suggest that informal employment comprises about one-half to three-quarters of non-agricultural employment in developing countries. Moreover, and perhaps even more significantly, these proportions appear to be rising even when economic growth is proceeding in developing countries, contrary to what a previous generation of researchers and policymakers had anticipated.").

33. Keith Hart, Bureaucratic Form and the Informal Economy, in LINKING THE Formal and Informal ECONOMY, supra note 11, at 21, 23, 27.

34. Id. at 26.

35. Dzodzi Tsikata, Towards a Gender Equitable Decent Work Regime for Informal Employment in Ghana: Some Preliminary Considerations, CAN. LAB. \& EMP. L. 
At a policy level, informalization is viewed approvingly in some sectors as a necessary adjustment to overly rigid and statist economic strategies. ${ }^{36}$ In the area of labor law, the deregulatory argument is phrased in terms of the need for labor flexibilization. ${ }^{37}$ Amongst critics of deregulation, however, the growth of "flexibilization" as a strategy for labor law reform has raised widespread concerns about its contribution to "precarious work": "The decline of the standard employment relationship and the increase in precarious work-work that is insecure, badly remunerated, unprotected, and largely beyond the control of employees-is one of the most worrying problems of the new economy." 38 Flexibilization is of concern everywhere, but in the developmental context it has the distinctive feature of having been part of a coherent reform agenda proposed by the international financial institutions. ${ }^{39}$

Of what significance is economic informalization and labor market flexibilization to the issue of domestic work, for which such characteristics are neither new nor exceptional? These dynamics form an important component of the background conditions within which domestic labor markets work. They shape not only bargaining

(forthcoming); Marilyn Carr \& Martha Alter Chen, Globalization and the Informal Economy: How Global Trade and Investment Impact on the Working Poor 2 (Women in Informal Employment Globalizing \& Organizing [WIEGO], Working Paper No. 1, 2002) ("the informal economy [has] continued to expand and grow").

36. Martha Alter Chen provides a comprehensive analysis of the literature:

Over the years, the debates on the informal economy crystallized into three dominant schools of thought: dualism, structuralism and legalism. The dualists argue that informal ... activities have few (if any) linkages to the formal economy ... and that informal workers comprise the less-advantaged sector of the informal market. Unlike the dualists, structuralists see the informal and formal economies as intrinsically linked ... capitalist firms ... are seen to reduce their . . . labor costs, by promoting informal production . . . both informal enterprises and informal wage workers are subordinated to the interests of capitalist development ... The legalists focus on the relationship between informal entrepreneurs/enterprises and the formal regulatory environment, not formal firms.

Chen, supra note 31 , at 84 ; see also Carr \& Chen, supra note 35, at 6 ("what distinguishes each of these schools is their underlying model of power or power relationships. The dualists subscribe to the notion that there are few (if any) power relationships between ... the informal and formal economies. The structuralists subscribe to the notion that the formal economy exerts a dominant power relationship over the informal economy in its own interests. The legalists subscribe to the notion that informal entrepreneurs exercise their own power.").

37. Dzodzi Tsikata criticizes this literature, arguing that, in terms of labor issues, there has not been a focus on development or sustainability, or livelihood security. See Tsikata, supra note 35, at 5 ("Dominated by the international financial institutions $\ldots$ and economists, policy discussions have stressed the importance of flexibility of labor markets for economic growth." ); see also Anne Trebilcock, Using Development Approaches to Address the Challenge of the Informal Economy for Labor Law, in Boundaries and Frontiers of Labor LaW 63 (Guy Davidov \& Brian Langille eds., 2006).

38. Rittich, supra note *, at 31 .

39. Id. at 35 . 
amongst particular contracting parties but also the possible directions of change in a broader context. Against a backdrop of increasing informality, the likelihood of domestic workers to be able to demand better terms and conditions, either individually or collectively, is greatly challenged. Moreover, the decline of formal, public sector opportunities in developing countries is affected by these trends. With economic informality more prevalent, livelihood alternatives may decrease.

\section{Specific Causes of Legal Informality Affecting African Asylum Seekers as Migrant Domestic WORKERS IN EGYPT}

Egypt is a major destination for asylum-seekers. ${ }^{40}$ In the migration lexicon, Egypt is a country of transit, meaning this destination is

40. The significant population of African asylum-seekers in Egypt can be attributed to a variety of interlocking factors. First, waves of intense political and military conquest and upheaval, as well as economic desperation, have expelled African asylum seekers from their countries of origin. Donald P. Chimanikire, African Migration: Causes, Consequences and Future Prospects and Policy Options (paper presented to the U.N. Univ. Conf., "Poverty, International Migration, and Asylum," Helsinki, Finland, Sept. 27-28, 2002). In addition to these "push" factors, are diverse "pull" factors attracting African asylum seekers to Egypt. Most African migrants enter Egypt from its southern border with Sudan. Munzoul A.M. Assal, Refugees from and to Sudan (paper prepared for the Migration and Refugee Movements in the Middle East and North Africa, The Forced Migration and Refugee Studies Program, American University in Cairo, Egypt, Oct. 23-25, 2007). Until recently, see infra text accompanying notes 96-99, the Egypt-Sudan border has not been heavily policed, certainly in comparison to the borders of proximate wealthier nations, i.e., Israel and Mediterranean Europe. Second, there are relative economic and political advantages of migration to Egypt. With its capital city Cairo as the largest on the African continent, Egypt at least promises economic and survival opportunities. As a territory that is relatively free of outright physical conflict-despite or because of its authoritarianism-Egypt offers a degree of stability and physical security. Cairo's history of relative cosmopolitanism must also factor in, as a city with ancient traditions of political, mercantile and cultural flux, and hybridity. Third, Egypt's legal culture has also been relatively hospitable. Following World War II, Egypt pursued aspirations of postcolonial leadership in the international community and the Third World. Accordingly, the Egyptian constitution grants political asylum to all who have defended "their people, human rights or justice." CoNST. OF THE ARAB REP. OF EGYPT art. 53 ("The right to political asylum shall be guaranteed . . . for every foreigner persecuted for defending the peoples' interests, human rights, peace or justice.").

This general posture of openness is particularly enhanced in the case of the Sudanese, since, as the Egyptian government recently put it, "the Sudanese in Egypt have always enjoyed a special status." U.N. Comm. on the Prot. of the Rights of All Migrant Workers and Members of their Families, Written Replies by the Government of Egypt Concerning the List of Issues Received by the Committee on Migrant Workers Relating to the Consideration of the Initial Public Report by Egypt, II 6, U.N. Doc. CMW/C/EGY/ Q/1/Add.1 (Feb. 6, 2007) [hereinafter Migrant Workers' Committee]. This charitably phrased description glosses over the colonial relationship of Egypt (as a proxy for Britain) over Sudan and the prejudices of many Egyptians against the Sudanese. Nevertheless, it does reflect geographical, historical, cultural, and linguistic ties that have resulted in various treaties granting mutual rights of, inter alia, entry and work, though the most recent of these treaties has not been fully implemented. YASMINE Ahmed \& Rebecca Dibb, Pandemic Preparedness Among Sudanese Migrants in 
nominally only temporary for most asylum seekers, though in reality asylum-seekers are in Egypt indefinitely, as they await the refugee status determination process. ${ }^{41}$ Asylum seekers gather in Egypt to seek recognition under international refugee law and subsequently resettlement to wealthier countries in the global North and the Middle East. ${ }^{42}$ The fact that many migrants in Egypt are attempting to resettle elsewhere adds to the context of precariousness. Despite the many forces of attraction bringing asylum seekers to Egypt, they face serious challenges to their everyday survival. Domestic work forms a significant source of livelihood for them. As a consequence, asylum seekers are also migrant workers, demonstrating the difficulty in distinguishing "political" from "economic" migrants. ${ }^{43}$ Without documentation in either category, they are also irregular migrants.

\section{A. Foreground Rules: Labor and Employment Law in Egypt}

Notwithstanding the regional and local particularities of Egyptian family law-an essential exposition of which can be found in Lama Abu-Odeh's Modernizing Muslim Family Law ${ }^{44}$-Egypt resembles the universalized model described elsewhere in this volume: it identifies much of what we understand as family law as a separate domain which does not include waged work. ${ }^{45}$ The informal and un-

GREATER CAIRo 14 (Center for Migration and Refugee Studies, American University in Cairo, 2008) ("[T] he 1976 Wadi El-Nil (Nile Valley) [agreement] granted [mutual rights] ... to enter and exit ... without visa requirements and unrestricted access to education, employment, health-care and ownership of property .... This agreement was revoked in 1995 after an assassination attempt on Hosni Mubarak blamed Sudanese Islamist extremists in Ethiopia. The sudden change in the law caused a number of Sudanese migrants, previously residing lawfully in Egypt, to find themselves ... in an irregular situation. . . . However, in 2004, Egypt signed the Four Freedoms Agreement ... [which] promised a partial return to the Wadi-El Nil Agreement . . .."). For criticisms of Egypt's lack of implementation of the Four Freedoms Agreement, see infra Part II.B.3. . The result of all of these factors is that the Sudanese are the largest group of foreign nationals living in Egypt, though the lack of data leaves a very wide estimated range of between two and five million. Migrant Workers' Committee, supra.

41. See infra text accompanying note 67.

42. Mundlak, supra note 22, at 6 (noting that irregular migrants that Israel deems "[i]ndividuals from enemy countries generally enter [by] crossing the border with Egypt.").

43. Assal, supra note 40 , at 6 (it is "difficult to procure neat boundaries between voluntary and forced migration. Whereas conventional wisdom in migration studies looks at refugees and migrants as having different motives for leaving a homeland (migrants for economic reasons, refugees for political reasons), recent studies show that a mixture of factors produces both categories.").

44. Lama Abu-Odeh, Modernizing Muslim Family Law: The Case of Egypt, 37 VAND. J. Transnat'L L. 1043 (2004).

45. See Halley \& Rittich, supra note 4; Duncan Kennedy, Savigny's Family/Patrimony Distinction and its Place in the Global Genealogy of Classical Legal Thought, 58 Ам. J. СомP. L. 811 (2010). 
regulated labor environment for domestic workers is constructed by law, most importantly through regulatory exclusion. ${ }^{46}$

Household labor, in the Middle East and North Africa, as elsewhere, provides a major source of livelihood for migrant workers. ${ }^{47}$ Egypt stands in contrast to other countries in the region, however, in its relatively low level of formally employed migrant domestic workers. Whereas in other states in the region, migrant workers are predominantly South Asians who have procured formal entry through the kafala system, ${ }^{48}$ in Egypt (where the majority of domestic workers are Egyptian) migrant domestic workers are predominantly "irregular" migrants from the Sudan and the horn of Africa. ${ }^{49}$ Due to the country's relative poverty, large population, and unemployment, such formal contracting for migrant household help is negligible. This contrast is reflected also in the national origins of the domestic migrant worker population to be found in Egypt, which are predominantly sub-Saharan African as opposed to the South Asians who supply the households of the Levant and the Gulf.

The origin of much of the migrant domestic worker population as asylum-seekers and other irregular migrants, rather than in a formal contracting system, alters the dynamics between employer and employee. Though employees can be vulnerable in both circumstances, widespread abuses arising in the kafala context-restrictions on freedom of movement and withholding of identity and travel documents-do not tend to pertain to the Egyptian context where many migrant workers are unlikely to have valid travel documents in the first place. Rather, the vulnerability of migrant domestic workers comes from the factors that contribute to their irregularity-the lack of formal opportunities to enter the country, and the exclusion of domestic work from labor law.

46. See Ray Jureidini, Irregular Workers in Egypt: Migrant and Refugee Domestic Workers, 11 INT'L J. MULTICULTURAL Soc'Ys 75-82 (2009).

47. The Middle East and North Africa have the "highest share of migrant populations in the world, if regular and irregular migration is included as well as refugees and asylum seekers." Jureidini, supra note 46 , at 77 . Migrants have historically constituted an important source of labor for the oil-producing Gulf states, Libya, Jordan and, increasingly in recent years, Israel. Philippe Fargues, Introduction to EUR. UNIV. Inst., ROBert Schuman Ctr. for Advanced Stud., Mediterranean Migration 20062007 Report (Philippe Fargues ed., 2007); ILO Regional OfFice for Arab States, Gender and Migration in Arab States: The Case of Domestic Workers 11 (Simel Esim \& Monica Smith eds., 2004); see Mundlak, supra note 22. The migrant population is greatly increased beyond "regular" migrants by substantial movements of refugees: "the Middle East is the world's largest source and host of refugees, constituting around 42 per cent of the total world refugee population." Jureidini, supra note 46, at 77 .

48. Elsewhere in the region, particularly the oil-producing Gulf states, Libya, and Jordan, the "kafala" system predominates whereby migrant workers enter into contracts prior to their entry into the country to work as household help. ILO REGIONAL OfFICE FOR ARAB STATES, supra note 47 , at 44.

49. Jureidini, supra note 46 , at 78 . 
Egyptian labor law (of which the most recent iteration is the Labour Law of 2003), provides: "Domestic work is an exception to labor law." 50 Reflecting the exceptionalism discussed in Part I above, the law is perhaps especially notable for also explicitly incorporating the justification for exceptionalism that draws on the context of intimacy in the household, as the law goes on to state: "This is because of the strong relations that grow between the servant and the employer which enables the former to know many secrets and personal issues of the employer." 51

In addition to establishing this exception from the labor law code, the statute also explicitly overrides the general employment-security default rules in Egypt by stating that otherwise applicable "restrictions on terminating the work contract do not apply to the employer in this case." 52

Unlike other states in the region, in Egypt no specific legislation has been adopted to promote or facilitate the process of hiring and entry for migrant domestic workers-a fact which stems from the vast differences in underlying economic conditions between Egypt, a poor, labor-rich, densely populated country, and other countries in the region that are wealthier and suffer from shortages of national labor supply.

To the contrary, over time and particularly with the economic decline of the 1980s and early 1990s, the government has adopted a strict stance discouraging regular migration for domestic workers. ${ }^{53}$ The Ministry of Labour and Immigration issued a decree in 1984 "specifically prohibiting foreign maids from entering Egypt."54 In 1987 the Ministry of Internal Affairs "launched a campaign to arrest those without proper work visas." 55

In 2003, migrant domestic workers were included in a broader tightening of Egyptian work visa rules requiring that foreign workers obtain a work permit before entering the country. In 2006, foreign domestic workers were specifically the focus of a further tightening of controls on entry, in a decree prohibiting the request of work permits

50. Labor Law, Law no. 12 of 2003 , art. $4(\mathrm{G})$; Jureidini, supra note 46 , at 79 .

51. Id.

52. Id.

53. The strict stance constitutes a change in enforcement rather than underlying law. The legislation itself has been in place since Nasser's regime, under which Law No. 91 was passed prohibiting the issuance of work permits to foreigners for positions that Egyptians could be hired to fill. In practice, the Ministry of Internal Affairs was lenient in enforcing this law, and many foreigners, among them migrant domestic workers, were allowed entry notwithstanding the general prohibition. Others intending to work entered on tourist visas, a practice that remains common in Egypt today.

54. Jureidini, supra note 46 , at 80 .

55. Id. 
for foreign nationals to perform household labor ("house manager or a similar position such as nanny, cook, maid"). .56

The context of these restrictions appears to have been a straightforward series of efforts to shore up employment opportunities for Egyptian nationals. ${ }^{57}$ Apparently to enable Egypt to remain compliant with its obligations under international refugee law, an exception to this strict prohibition allows a work permit to be obtained through special petition in cases of "humanitarian and social" necessity. ${ }^{58} \mathrm{As}$ the next section indicates, however, in practice this permission has not materialized, so that obtaining formal work permits remains practically impossible regardless of refugee or asylum-seeker status.

\section{B. Background Rules: Migration and the Right to Work in Egypt for Asylum-Seekers}

If foreground rules on labor and employment codes and regulations in Egypt provide virtually no protection for domestic workers; their relative bargaining power is affected by background rules relating to their status in the country. With the right to work legally in the country, migrant domestic workers would occupy a stronger position since they need not fear and cannot be threatened with arrest and deportation.

Egypt has entered into a significant number of treaties that do, by virtue of their subject matter, potentially apply to migrant domestic workers. That these treaties have been ratified, and that they are directly enforceable, makes them an important part of the legal framework. However, as the close readings below reveal, that framework often ends up mirroring, in form or in effect, the regulatory exclusion in the Egyptian labor code. As such, it reinforces the dynamic of informality that pervasively defines these workers' experiences.

56. Id. at 82 .

57. At the same time, the Egyptian government was acceding to greater trade liberalization on traditional goods through the World Trade Organization. The coincidence of these work restrictions with WTO accession may either have been evidence of the lack of coherence in domestic economic regulation, or evidence of a strategy to provide some economic security in a context where foreign import competition might otherwise be undermining employment opportunities.

58. Id. at 82 :

In 2006 the Egyptian Government placed strict control on the formal entry of foreign domestic workers. Decision (700), article (11) states: It is prohibited to request a work permit for foreigners for the occupations of house manager or a similar position such as nanny, cook, maid, etc. of any nationality. It can only be obtained in writing from the central administration of labour from the ministry and in cases where humanitarian and social circumstances necessitates and after consulting with the minister.

According to Egyptian law, therefore, once a treaty is ratified and published, no additional step of implementing legislation is required for it to take domestic legal effect. 
The right to work for African asylum-seekers in Egypt who are migrant domestic workers is potentially offered by international law through a series of treaties on the treatment of refugees, the human rights of migrant workers and their families, international labor standards, and transnational criminal law. Each of the respective conventions is part of a broader treaty regime offered by, respectively, the UN High Commissioner for Refugees, the UN Human Rights Committee, the International Labor Organization, and the UN Office on Drugs and Crime.

With the exception of some ILO conventions, all of the treaties are directly enforceable as a matter of Egyptian law. ${ }^{59}$ This direct legal effect stands in contrast with non-self-executing jurisdictions where implementing legislation is required for treaties to become domestically applicable. In Egypt, once ratified treaties have been officially published by the Egyptian government, "[t]heir provisions are equivalent to those of applicable Egyptian law and may be invoked before all legislative, executive and judicial authorities of the State."60

Of course, the formal enforceability of treaties in Egypt does not guarantee their automatic application. There is a complex negotiation between the Egyptian judicial and executive branches vis-à-vis various aspects of the nation's laws. Courts have applied international human rights treaties provisions directly, sometimes politically challenging the executive branch. ${ }^{61}$ At the same time, the

59. These treaties are held by the Egyptian Constitution to possess "the force of law." Const. OF THE ARAB REPUBLIC OF EGYPT, art. 151, available at: http://www.elshoura.gov.eg/shoura_en/const_pdf/eng_const.PDF. The direct legal effect of ratified and published treaties has been confirmed in Egyptian jurisprudence. See General Prosecution case 4190 (Supreme State Security Court, 1986) (cited in TAREK BADAWY, Comments on Egypt's Report to the Committee on the Protection of the Rights of All Migrant Workers and Members of Their Families 3 (2007). It has also been confirmed by the Egyptian executive branch in its reporting to the United Nations, for example on its obligations under the Convention on the Rights of Migrant Workers and Their Families discussed below. See U.N. Comm. on the Prot. of the Rights of All Migrant Workers and Members of their Families, Consideration of Reports Submitted by States Parties under Article 73 of the Convention, Initial Report of States parties due in 2004: Egypt, U.N. Doc. CMW/C/EGY/1 (Aug. 21, 2006), paras. 12 \& 13:

[I]nternational treaties in general are governed by the provisions of article 151 of the Permanent Constitution of 1971 , which provides that following completion of the requisite constitutional procedures, treaties are deemed to constitute part of Egyptian law. Accordingly, following their ratification and publication, international instruments concerned with human rights and freedoms, including the International Convention on the Rights of All Migrant Workers and Members of Their Families, are regarded as being equivalent to laws enacted by the legislative authority. Their provisions are equivalent to those of applicable Egyptian law and may be invoked before all legislative, executive and judicial authorities of the State.

60. Id.

61. Awad el-Morr, The Supreme Constitutional Court of Egypt and the Protection of Human and Political Rights, in IsLAM AND PuBlic LAw 229 (Chibli Mallat ed., 1993). 
executive branch has advanced a variety of strategic moves designed to minimize the role of the judiciary and of constitutional protections, for example by amending the constitution to reduce the judiciary's power $^{62}$ (through approval in a national legislature which, as a parliamentary system, includes a majority of legislators who belong to the same political party as President Mubarak). Though the constitutional provision establishing the force of law of treaties has not (yet) been amended, other constitutional amendments have necessarily changed the overall balance of power between various branches of government and the environment in the judicial system.

As in many legal systems, the enjoyment of any particular right in Egypt is therefore dependent on an array of institutional, political, and societal factors. This balance of power requires a more nuanced portrayal of Egypt than as either a police state in which individual constitutional and human rights have no real impact, or as an ideal system in which all such rights are given full legal effect.

Beyond this general limitation on the effect of treaties in Egypt, there are particular types of limitations that may further hamper the effect of special frameworks set forth by particular instruments. These limitations, de jure and de facto, have the overall result of lessening labor protections that would extend to the migrant domestic workers in this study. Both types of limitations will be discussed below.

\section{International Refugee Law in Egypt}

International refugee law provides refugees in Egypt the same right to work as the country accords to other foreign nationals. ${ }^{63}$ However, a number of obstacles stand in the way of full enjoyment of this right. First, the Egyptian government has been reluctant to recognize fully the right to work of refugees in its territory. Identity documents issued to refugees explicitly prohibited working, apparently in violation of Egypt's international law obligations, until

62. Nathan J. Brown, Michele Dunne, \& Amr Hamzawy, Egypt's Controversial Constitutional Amendments (Carnegie Endowment for International Peace, 2007).

63. Egypt has a reservation to the Refugee Convention's requirement that recognized refugees enjoy equality with Egyptian nationals insofar as national labor legislation and social security provisions are concerned. See Convention Relating to the Status of Refugees art. 24(1), July 28, 1951, 189 U.N.T.S. 137. However, Egypt has made no similar reservation to the Convention's requirement that recognized refugees benefit from the rules awarded other foreign nationals regarding the right to work. Id. art. 17(1) ("The Contracting States shall accord to refugees lawfully staying in their territory the most favourable treatment accorded to nationals of a foreign country in the same circumstances, as regards the right to engage in wage-earning employment."). That means refugees should be able to obtain a work permit if they go through the appropriate channels, as has been argued by the refugee advocate community in Egypt. Interview with Michael Kagan, Senior International Human Rights Fellow, American University in Cairo (Feb. 4, 2009). 
recently when that practice finally ended under pressure from the refugee advocacy community. ${ }^{64}$ Second, even with the path eased somewhat by the change in identity documents, other serious social and economic barriers stand in the way of the exercise of the right to work by lawful refugees. ${ }^{65}$ The process of obtaining work permits for foreign nationals that refugees would have to undergo is very timeconsuming, so that even in highly-paid and otherwise formal economic sectors, it is not uncommon for employees to be working without formal permits. In other words, labor informality pervades even traditionally formal sectors of the Egyptian economy.

Third, the right to work enjoyed by recognized refugees suffers from the limitation that recognized refugees form only a small subset of the population of asylum-seekers in Egypt. For example, though the total number of Sudanese nationals in Egypt is estimated at between two and five million, only about thirteen thousand are officially recognized as refugees. ${ }^{66}$ The process of refugee status determination in Egypt has been criticized for both its delays ${ }^{67}$ and its improper tendency to under-recognize refugee status claims. As an example of both problems, in 2004 the UN High Commissioner on Refugees (UNHCR) suspended all refugee status investigations for

64. As indicated supra, this prohibition appeared to have violated Egypt's obligations under Article 17 of the Refugee Convention. As an apparent compromise in the face of the violation charge by refugee advocates, refugees' identity documents now are completely silent as to work permission. Theoretically, therefore, refugees should now be able to apply for and obtain work permits using the same channels as other lawfully present foreign nationals in Egypt.

65. Neither the UNHCR nor the NGO community that supports asylum seekers in Cairo has devoted more than minimal attention to the issue of work permit, given the many pressing claims on resources and the need for attention to ensuring physical security and providing advocacy in the status determination process. Interview with Shahid Haque, Regional Representative for the Middle East, International Organization for Migration, in Cairo, Egypt (Feb. 12, 2009); Interview with Mario Tavolaj, Special Envoy, International Organization for Migration, in Khartoum, Sudan (Feb. 17, 2009); Interview with Intake Staff, All Saints Cathedral, in Cairo, Egypt (Feb. 13, 2009). These offices focus mainly on assisting in refugee resettlement and return, as well as providing basic support services. Some NGOs do provide assistance to asylum seekers in gaining employment, and in particular in placing them in household employment. However, the lack of legal clarity surrounding the right to work, coupled with the precarious positions of both asylum seekers and NGOs in Egypt, mean that any employment advocacy provided regarding terms and conditions of work tends to be highly informal. Interview with All Saints Cathedral, supra.

66. Egyptian Initiative for Personal Rights (EIPR) \& International Federation for Human Rights (FIDH), Egypt: Protection of the Rights of All Migrant Workers and Members of Their Families, NGO Alternative Report to the UN Committee on the Protection of the Rights of All Migrant Workers and MemBERS OF TheIr FAMILIES 9 (2007) [hereinafter EIPR \& FIDH]. Though this discrepancy reflects in part the many Sudanese nationals in Egypt who are not asylum seekers, the proportion of recognized refugees to asylum-seekers is estimated to be well under one to ten.

67. Tarek Badawy, Comments on Egypt's Report to the Committee on the Protection of the Rights of All Migrant Workers and Members of Their FAMILES 5 (2007). 
Sudanese asylum-seekers, following a ceasefire agreement in the north Sudan-south Sudan civil war, on the grounds that political conflict technically no longer existed in Sudan. The idea that political upheaval had suddenly vanished, and that Sudanese asylum-seekers were fully safe in returning home, was questioned by many. Dismay and outrage against the UNHCR's suspension of refugee claims eventually led Sudanese asylum-seekers in late 2005 to stage protests, sitins, and other civil disobedience in the Cairene suburb where the UNHCR office was located. This civil disobedience was abruptly and brutally halted by the Egyptian police in an action that resulted in the deaths of twenty-eight protesters. ${ }^{68}$

The limitations of the refugee status determination process reflect in part the dearth of administrative capacity in the wake of large demand from asylum-seeking communities. ${ }^{69}$ Yet, as the 2005 incident demonstrates, the problems with the refugee status determination process also result from a political context in which the Egyptian government feels little accountability to the asylum seeker communities, and in which the UNHCR is constrained by its status both as a guest of the Egyptian government and a servant of the international community of states. Moreover, wealthy countries who would ostensibly provide resettlement for refugees have their own reasons for resisting the refugee recognition and resettlement process.

\section{International Law on Migrant Workers in Egypt}

The UN Convention on the Rights of Migrant Workers and Their Families (the Migrant Workers' Convention) excludes refugees, ${ }^{70}$ reinforcing the dichotomy between "forced" migration for political reasons and "voluntary" migration for economic reasons, and securing a division of labor between the international law applying to these two categories. While conceptually questionable, the scope of the Migrant Workers' Convention does provide a source of protection under international law for the migrant workers in Egypt who are

68. Assal, supra note 40, at $7 \mathrm{n} .2$ ("The brutal onslaught by Egyptian police forces on Sudanesse refugees in Cairo sheds light on a horrendous human tragedy. Over five thousand policemen armed with sticks and shields broke up the small square where the Sudanese refugees had been camping at around 5:00 am Friday, December 30, 2005. Twenty-eight Sudanese refugees were killed while many others injured.").

69. Low institutional capacity characterize both the Egyptian governmental offices responsible for the process, and the Egyptian offices of the UNHCR, which conducts the bulk of the process on behalf of the government. Michael Kagan, Seeking Asylum in the Middle East: State-to-UN Responsibility Shift and the Challenge of Finding a Foundation for Refugee Policy in a Troubled Region (unpublished manuscript, on file with author) (presented at American University in Cairo, Department of Law Faculty Workshop, Feb. 21, 2008).

70. International Convention on the Protection of the Rights of All Migrant Workers and Members of Their Families art. 3, Dec. 18, 1990, 2220 U.N.T.S. 93 [hereinafter Migrant Workers' Convention]. 
asylum-seekers but who have not received formal recognition as lawful refugees-in other words, for the remainder of "irregular" migrants. ${ }^{71}$

The Migrant Workers' Convention is arguably a "significant rights document for legal migrant workers,"72 requiring states parties to afford them, for example, treatment equal to nationals in health and social services. ${ }^{73} \mathrm{~A}$ trickier question is what protection the Convention provides for irregular migrant workers. In the perennial tension between human rights and sovereignty, where does the Convention stand-does it reinforce sovereignty by circumscribing human rights claims only to those workers whose presence has been authorized by the state, or does it dare to cross the final frontier of sovereignty by insisting that even workers whose presence is unauthorized enjoy some rights by virtue of their humanity?

The Convention does contain a broadly stated principle of nondiscrimination that could be read expansively to include irregular migrants. ${ }^{74}$ However, this language does not explicitly include documentary status. Given the importance of documentary status in migration law, doctrine, and practice, this absence suggests an intentional omission. That documentary status is excluded as a basis for protection under these broad introductory nondiscriminatory provisions is further supported by considering it in the context of the entire document, which contains sub-sections explicitly accorded to "all" migrant workers regardless of documentary status (Part III), and to only documented workers (Part IV). ${ }^{75}$ Even if the more expansive interpretation were to be adopted, the extension of nondiscrimination to migrant workers regardless of documentary status would apply to only those substantive rights provided in Part III on the "Human Rights of All Migrant Workers," since the other two

71. See supra Part I.B. (defining irregular migration).

72. Catherine Dauvergne, Making People Illegal: What Globalization Means for Migration and Law 26 (2008).

73. Migrant Workers' Convention, supra note 70, art. 43.

74. Article 1 establishes an apparently broad scope, applying to "all migrant workers ... . without distinction" and specifying applicability to "all migrant workers and members of their families without distinction of any kind such as sex, race, color, language, religion or conviction, political or other opinion, national, ethnic or social origin, nationality, age, economic position, property, marital status, birth or other status." Migrant Workers' Convention, supra note 70, art. 1. Similarly, Article 7 in Part II of the Convention sets forth a basic nondiscrimination norm, providing that:

States Parties undertake, in accordance with the international instruments concerning human rights, to respect and to ensure to all migrant workers and members of their families within their territory ... the rights provided for in the present Convention without distinction of any kind such as to sex, race, colour, language, religion or conviction, political or other opinion, national, ethnic or social origin, nationality, age, economic position, property, marital status, birth or other status."

75. Dauvergne, supra note 72 , at 22-25. 
Parts ${ }^{76}$ are limited explicitly to workers with "regular or documented" status.

Nevertheless, because Part III "reiterat[es] commitments set out in other, generally applicable, human rights documents,"77 such as the right to life, ${ }^{78}$ freedom from torture ${ }^{79}$ and enslavement, ${ }^{80}$ freedom of expression, ${ }^{81}$ and due process protections against arbitrary detention, trial, and expulsion, ${ }^{82}$ it could be read as strengthening the position of irregular migrant workers under international law by extending some important general human rights to them, or at least clarifying that these rights apply to them. ${ }^{83}$

Yet close legal analysis of Part III suggests that it may be clarifying the rights of irregular migrants in the direction of reduced rather than expanded protection. An examination of the human rights to freedom of expression, association, and assembly provides an instructive example. Whereas expression, association, and assembly relate to each other practically and conceptually, they are often separately specified under international law and therefore denote distinct rights. ${ }^{84}$ The Migrant Workers' Convention references freedom of expression and only a limited right to join and take part in, but not form, associations in its provisions applying to "all" migrant workers. Given the importance of the freedoms of association and assembly for workers, including migrant domestic workers, this omission could be read as intentionally allowing for lesser protection of those freedoms as exercised by undocumented migrant workers. This lesser level of protection is further clarified by contrasting Part III, applying to irregular migrant workers, with Part IV which does explicitly provide the right to form associations to workers with regular documentary status. ${ }^{85}$

76. See Migrant Workers' Convention, supra note 70, Part IV (addressing those who "are documented or in a regular situation"), Part V (limiting the rights established under Part IV for regular workers in "particular categories" of work).

77. DAUVERGNE, supra note 72 , at 25.

78. Migrant Workers' Convention, supra note 70, art. 9.

79. Id. art. 10

80. Id. art. 11

81. Id. art. 13 .

82. Id. arts. 14-23.

83. DAUVERGNe, supra note 72 , at 25.

84. For example, the International Covenant on Civil and Political Rights (ICCPR) contains the right to freedom of expression, the right to peaceful assembly, and the right to freedom of association. International Covenant on Civil and Political Rights [ICCPR], Dec. 16, 1966, 6 I.L.M. 368 (entered into force on Mar. 23, 1976); see also id. art. 19 (freedom of expression); art. 21 (peaceful assembly); art. 22 (freedom of association). The ICCPR also includes a nondiscrimination provision that is similar to that of the Migrant Workers' Convention, including the incorporation of the catchall "other status" term. Id. art. 2(1).

85. Compare Migrant Workers' Convention, supra note 70, art. 40 (providing that the freedom of association can only be restricted by concerns related to national security and public order) with id., art. 26. 
While this omission can be viewed as an effort to respect the sovereignty of states parties, and more broadly to recognize the importance of the rule of law, it may nevertheless contribute to the deepening of a worker underclass without rights of resistance to employer abuse. The effects of denying full freedoms of assembly and association to undocumented workers may paradoxically be to increase lawlessness and insecurity by allowing employers to destabilize workplace protections, as dissenting U.S. Supreme Court Justice Breyer stated in a controversial decision reversing existing federal case law on the applicability of labor rights and remedies to undocumented workers in the United States. ${ }^{86}$

A recent addition to international and Egyptian law, the Migrant Workers' Convention entered into force in 2003 and was ratified by Egypt in 2003. Notwithstanding its entry into force, states parties to the treaty reflect an imbalance between poor, "sending" countries and rich, "receiving" countries (none of whom are states parties) and the greater incentive of poorer countries to establish protections for migrants who are primarily their nationals. ${ }^{87}$

Egypt, like many developing countries, both sends and receives migrants. ${ }^{88}$ Thus, although Egypt's incentive in joining the Migrant Workers' Convention may have been to accord benefits to its nationals working abroad, its significant migrant population also creates potential obligations.

The ineffectiveness of criminal process rights was recently examined by the UN body monitoring the Migrant Workers' Convention in the context of Egypt's regular reporting on implementation. ${ }^{89}$ Among other things, Egypt's report included an exposition of the ways in which national law reflects the Convention's protections for

86. See Hoffman Plastic Compounds, Inc. v. National Labor Relations Board, 535 U.S. 137 (2002); id. at 155 (Breyer, J., dissenting) (internal citations omitted) ("denial [of labor law remedies] lowers the cost to the employer of an initial labor law violation (provided ... that the victims are illegal aliens)").

87. The states party "are comprised entirely of countries who primarily send rather than receive migrants .... All the states party are in the lowest two-thirds of countries according to . . GDP per capita." DAUVERGNe, supra note 72, at 23.

88. With its large population and high unemployment, it unsurprisingly exports large numbers of workers, primarily to the Arab world but also to the global North. However, due to its relative economic and political strength vis-à-vis many of its neighbors as discussed above, Egypt also is a significant receiving country.

89. U.N. Comm. on the Prot. of the Rights of All Migrant Workers and Members of their Families, Consideration of Reports Submitted by States Parties under Article 73 of the Convention, Initial Report of States Parties Due in 2004: Egypt, U.N. Doc. CMW/C/EGY/1 (Aug. 21 2006). 


\section{all migrant workers against discrimination ${ }^{90}$ and arbitrary} detention. ${ }^{91}$

As a recent commentary on Egypt's Report on the Migrant Workers' Convention observes, however, "Egypt has been under a state of emergency for more than a quarter of a century, which grants the police the right to ask any individual for identification at any time." 92 Despite the Egyptian government's suggestion to the contrary before the UN Migrant Workers' Committee, ${ }^{93}$ the authoritarianism of the Egyptian government was closely associated with arbitrary detentions, torture, and harassment by the police in accompanying submissions by Egyptian $\mathrm{NGOs}^{94}$ and in other human rights documentation. ${ }^{95}$

Moreover, though deportations have been historically rare, 96 they have recently increased partially under pressure from neighboring industrialized countries, Southern Europe and Israel, who are trying to decrease migration of African asylum seekers moving into

90. Id. at 31 , para. 65 (citing a constitutional case which establishd that "every individual, whether citizen or alien, has ready access to [Egypt's] courts of law and enjoys protection of the rights laid down in [Egyptian] legislation" for the (subtly framed) proposition that "an alien, regardless of the legal basis of his presence in the country, enjoys all aspects of the protection available under the law." (emphasis added).

91. Id. at 45, para. 124 "All persons held in detention, regardless of whether they are Egyptian citizens or aliens, enjoy the same safeguards available under the law, without distinction or discrimination."). Again, this statement is subtly worded, avoiding the question of whether aliens have lesser rights regarding the initial process of detention and focusing only on rights enjoyed by persons once "held in detention."

92. BADAWY, supra note 67 , at 4 .

93. Migrant Workers' Committee, supra note 40, at II 3 ("The Egyptian Emergency Act No. 162 of 1958 is in conformity with article 4 of the International Covenant on Civil and Political Rights, concerning the international rules and norms for dealing with exceptional situations which endanger society. In accordance . . , the declaration of the state of emergency in the country does not give rise to the suspension of the Egyptian Constitution or of the State's domestic institutions. By law, the legislature ... must approve a declaration, and any extension, of a state of emergency."). This statement does not discuss what happens once the legislature does approve a state of emergency, which approval has been granted by the Egyptian legislature.

94. See BADAwY, supra note 67; EIPR \& FIDH, supra note 66 , at 8 (relating arbitrary and racially motivated detentions, as well as "torture and ill-treatment ... in all places of detention in all parts of the country").

95. See, e.g., U.N. Comm. Against Torture, Conclusions and Recommendations of the Committee against Torture: Egypt, If 5(b), U.N. Doc. CAT/C/CR/29/4 (Dec. 23, 2002) (detailing "the many consistent reports received concerning the . . phenomenon of torture and ill-treatment of detainees by law enforcement officials, and the absence of measures to ensure effective protection and prompt and impartial investigations. Many of these reports relate to numerous cases of deaths in custody."); U.N. Human Rights Comm., Concluding Observations of the Human Rights Committee: Egypt, II 13, U.N. Doc. CCPR/CO/76/EGY (Nov. 28, 2002) ("The Committee notes with concern the persistence of torture and cruel, inhumane or degrading treatment at the hands of law-enforcement personnel, in particular the security services, whose recourse to such practices appears to display a systematic pattern.").

96. BADAwY, supra note 67, at 5 (generally, "the Egyptian government rarely deports asylum-seekers or refugees"). 
their own territories. ${ }^{97}$ Such pressure has resulted in extremely dangerous tactics: according to a recent Human Rights Watch report, Egyptian border forces killed at least thirty-three African migrants trying to cross into Israel between July 2007 and October 2008.98 Amnesty International lawyers have mobilized legal defense efforts against deportations of asylum-seekers, of whom Eritreans fleeing a brutal crackdown in their own country most recently form a significant share. ${ }^{99}$

Despite these terrible circumstances, the very fact that they have been vocally reported by Egyptian NGOs provides a basis for hope in the form of increased awareness and political mobilization. In addition to the precarious status of NGOs in Egypt, ${ }^{100}$ however, any such optimism would need to be qualified by the subsequent decline in advocacy on migrant worker issues. As one NGO executive explained, this withdrawal came with the realization that the UN reporting process exercised little effective constraint, together with a general context of lack of resources and security. ${ }^{101}$

\section{Sudanese Migrants and the Four Freedoms Agreement}

Signed in 2004, the Four Freedoms Agreement is supposed to give citizens of Egypt and Sudan equal rights with regards to entry, residence, employment, and movement between the two countries. As a matter of principle, this agreement should provide Sudanese migrant workers in Egypt with full equality under the law.

97. Rebecca Collard, Run for the Border, EgYPT TodAy, Jan. 2009. An extreme version of this dynamic occurred in neighboring Libya in 2007, when, after Libya had "successively opened [its] borders and territory to Arabs in the name of Pan-Arabism, then to Africans in the name of Pan-Africanism," it suddenly imposed restrictions on these groups "in repudiation of agreements passed in the framework of the Community of Sahel-Saharan States and the Arab Maghreb Union-to please Europe at a time when the country had become a major gateway for irregular migrants from Africa." Fargues, supra note 19, at 2.

98. See also Human Rights Watch, Sinai Perils: Risks to Migrants, Refugees, and Asylum Seekers in Egypt and Israel 34 (2008).

99. Interview with Mohamed Lotfy, Campaigner, Middle East and North Africa Programme, Amnesty International (Feb. 8, 2009).

100. Human Rights Watch, Egypt: Margins of Repression-State Limits on NON-GovernMENTAL ORGANIZATION ACTIVISM (July 2005), available at http://hrw.org/ reports/2005/egypt0705/index.htm.

101. Interview with Hossam Bhagat, Executive Director, Egyptian Initiative for Personal Rights (Feb. 4, 2009). Bhagat explained that, in his opinion, Egypt "understands very well" that it can indefinitely prolong investigations and findings under the UN reporting process, by simply issuing denials in response to repeated UN follow-up queries, such as those contained in U.N. Comm. on the Prot. of the Rights of All Migrant Workers and Members of their Families, Written Replies by the Government of Egypt Concerning the List of Issues Received by the Committee on Migrant Workers Relating to the Consideration of the Initial Public Report by Egypt, U.N. Doc. CMW/C/EGY/Q/1/Add.1 (Feb. 6, 2007). 
The implementation of the agreement has been extremely slow. ${ }^{102}$ The agreement does not specify which documents are necessary to enjoy these rights and may not apply to Sudanese who do not have national identity documents. Asylum-seekers who left Sudan under conditions of extreme haste would be particularly unlikely to possess such documents, and those fearing political persecution by their government would probably not be able to obtain such documents from their government's consulate officers in Egypt.

Moreover, "[i]n practice, the Sudanese are still required to have a visa to enter Egypt." 103 If there is any clear implication of the Agreement, it is not the expansion of protections for migrant workers, but rather the reduction of protection for Sudanese refugees whose formal recognition of refugee status in Egypt has been extinguished by virtue of the Agreement, according to the Egyptian government. ${ }^{104}$ In other words, this "special treatment" seems to have placed Sudanese residents in legal limbo, not having obtained the formal rights promised by the Egypt-Sudan treaty and with even less chance of protection under other treaties in force in Egypt.

\section{The International Labor Organization in Egypt}

The extension of the freedoms of association and assembly to undocumented migrant workers also appears to be granted under international labor law as established and interpreted by the International Labor Organization. ${ }^{105}$

More specifically in relation to domestic workers, while a minority of ILO Conventions explicitly allow for the exclusion of domestic workers, ${ }^{106}$ the majority simply do not mention them..$^{107}$ In the latter category is the ILO Convention on Migrant Workers. Within the ILO,

102. See, e.g., Gamal Nkrumah, Four Rights Go Wrong?, Al-Ahram WeekLy, Sept. $8,2004$.

103. BaDAWY, supra note 67 , at 9.

104. Migrant Workers' Committee, supra note 40.

105. Freedom of association is protected by the ILO's Convention on the Freedom of Association and Protection of the Right to Organize (ILO Convention No. 87), which on its own terms applies "without distinction whatsoever," as well as the Convention on the Right to Organize and Collective Bargaining (ILO Convention No. 98). Additionally, the freedom of association is recognized as one of the four "core" rights of international labor law by the 1998 Declaration on Fundamental Rights and Principles at Work, and held by the ILO to be applicable to all of its members regardless of whether they have specifically ratified the relevant conventions. The specific issue of the undocumented migrant came before the ILO Committee when U.S. and Mexican labor unions filed a complaint alleging that a 2002 U.S. Supreme Court decision violated U.S. obligations under international labor law. For a more thorough discussion of this case, see Chantal Thomas, Convergences and Divergencies in International Legal Norms on Migrant Labor, Comp. LAB. L. \& PoL'y J. (forthcoming, 2011).

106. 2010 ILO Report, supra note 1, at 22 (listing ten ILO Conventions that allow exclusions for domestic workers).

107. Adelle Blackett, Making Domestic Work Visible: The Case for Specific Regulation (ILO Labor Law and Labor Relations Programme, Working Paper No. 2, 1998). 
the "specificity"108 of domestic work has been the primary justification articulated for resistance to the active inclusion of it in generally applicable international labor standards. This reflects a more general dynamic in which the monitoring bodies of the ILO have been able to add to formal treaty obligations. ${ }^{109}$ When combined with the practical barriers to enforcement, this omission has the effect of rendering domestic workers "fundamentally invisible."110

Notwithstanding the absence of domestic work in the explicit provisions of ILO Conventions, the monitoring bodies of the ILO have gradually worked to establish an expansive interpretative stance that would include domestic workers in the scope of a Convention unless explicitly excluded. ${ }^{111}$ Thus, for example, the ILO's Committee of Exports on the Application of Conventions and Recommendations (CEACR) has found that ILO standards against forced labor ${ }^{112}$ and for freedom of association ${ }^{113}$ apply to migrant domestic workers.

Although Egypt is a member of the ILO, it has not signed on to the ILO Migrant Workers' Convention. However, for the reasons discussed above, the fact that the ILO Convention on migrant workers is not ratified by Egypt is not, in the ILO legal context, a persuasive justification for failing to extend labor standards to migrant domestic workers. In this context, a prevalent aspect of the ILO's institutional identity is the monitoring of "compliance with unratified treaties and other nonbinding norms and standards."114

108. 2003 ILO Report, supra note 8 , at $8 ; 2010$ ILO Report, supra note 1 , at 24 .

109. 2010 ILO Report, supra note 1, at 17.

110. Blackett, supra note 107.

111. Laurence R. Helfer, Monitoring Compliance with Unratified Treaties: The ILO Experience, 71 LAW \& CoNTEMP. Probs. 195, 195 (2008). Helfer explains how the ILO has gradually accumulated this authority, which is distinctive for its defiance of both principal-agent theory and the international law doctrine of sovereign consent. See id. at 196-97. Helfer "challenges the view that the ILO's . . . [monitoring] authority is inconsequential," articulating a variety of consequences that flow from monitoring, including promoting informal enforcement by other states and domestic advocacy.

112. 2010 ILO Report, supra note 1, at 18-19.

113. Freedom of association is protected by the ILO's Convention on the Freedom of Association and Protection of the Right to Organize (ILO Convention No.87), which on its own terms applies "without distinction whatsoever," as well as the Convention on the Right to Organize and Collective Bargaining (ILO Convention No. 98). Additionally, the freedom of association is recognized as one of the four "core" rights of international labor law by the 1998 Declaration on Fundamental Rights and Principles at Work, and held by the ILO to be applicable to all of its members regardless of whether they have specifically ratified the relevant conventions. The specific issue of the undocumented migrant came before the ILO Committee when U.S. and Mexican labor unions filed a complaint alleging that a 2002 U.S. Supreme Court decision violated U.S. obligations under international labor law. ILO Comm. on the Freedom of Ass'n, Complaints Against the Government of the United States Presented by the American Federation of Labor and the Congress of Industrial Organizations (AFLCIO) and the Confederation of Mexican Workers (CTM), I 605, Report No. 332, Case No. 2227, Vol. LXXXVI, 2003, Series B, No. 3 (Oct. 18, 2002).

114. Helfer, supra note 111 , at 195. 
Nevertheless, such formal logic does inform the ILO Sub-Regional Office in Egypt which has stated that, because Egypt is not a signatory to the ILO Convention on migrant workers, the ILO has no authority to investigate or advise on the status of migrant workers. ${ }^{115}$ In reality, the fact that the ILO Sub-Regional Office has minimal staff and resources has probably contributed to its reluctance to extend attention to migrant domestic workers. Rather, the office has focused on advising and supporting tripartite discussions between the Egyptian government, employers, and trade unions. More recently, it has incorporated a focus on antitrafficking and has joined a national consortium on the issue led by the first lady of Egypt, Suzanne Mubarak, and including the Egypt offices of the UN Office on Drugs and Crime, the International Organization on Migration, and other bodies.

5. The International Law Against Trafficking and MigrantSmuggling in Egypt

As indicated in the preceding section, the Egyptian environment has featured a growing awareness of and policy focus on antitrafficking efforts. Egypt is a signatory to both the UN Trafficking Protocol and the UN Migrant Smuggling Protocol.

The problem of trafficking is clearly significant amongst migrant domestic workers. "Domestic workers, predominantly women, are ... at particular risk of forced labour because of their isolated circumstances within private homes, and also because in many cases they are not protected by national labor law .... [m]igrant domestic workers can be most vulnerable."116

The juridical and conceptual line between trafficking victims and smuggled migrants reproduces the dichotomy between involuntary and voluntary migration that distinguishes refugees from migrant workers. This dichotomy, as discussed above, too simplistically characterizes scenarios that often combine both elements. The blurriness of the line between trafficking victims and smuggled migrants has, similarly, been noted as a challenge for coherent and just application of these treaties.

Even the greater protections under the Trafficking Protocol for migrants offer very little in the way of concrete help. Rather, these provisions for assistance and respect for human rights are aspirational and hortatory. If anything, the Trafficking Protocol seems instead to bolster the authority of the state. This effect comes from both the Protocol itself, which contains strong border control mea-

115. Interview with Alia Jamal, Senior International Labor Standard Specialist, International Labor Organization Sub-Regional Office for North Africa (Feb. 3, 2009).

116. International Labor Organization, The Cost of Coercion 29, para. 139 (2009). 
sures, ${ }^{117}$ and from various initiatives to achieve its implementation, such as U.S. State Department policies that reward other governments for boosting anti-trafficking enforcement. ${ }^{118}$

Particularly given the scant concrete protections for victims, such dynamics seem likely to increase authoritarianism in many instances. Although the Protocol has not yet been widely implemented in Egypt, its visible embrace by national agencies in a governance context of regular allegations of arbitrary detentions and torture raises this concern.

\section{Bargaining under Conditions of Informality}

U.S. legal scholars of both the household and the market have studied economic informality of various types, each with the question of how these two "private" zones interact with the prospect of public regulation. With respect to the household, Robert Mnookin and Lewis Kornhauser introduced the phrase "bargaining in the shadow of the law" to describe divorce proceedings in the context of private negotiation and public dispute resolution. ${ }^{119}$ With respect to the market, law and economics scholars have frequently studied "private ordering"120 and its possible efficiencies and inefficiencies as against the "centralized" intervention of the state. ${ }^{121}$ In keeping with the liminal legal category of domestic workers described above, this essential analytical rubric has seldom been applied to their case in legal scholarship. ${ }^{122}$ What are the bargaining power dynamics and what affects the balance or imbalance of power?

Some literature on private ordering suggests that the value of reputation-reputational costs and benefits-provides incentives to contracting parties to treat each other reasonably and in good faith. For such reputational incentives to work, however, contracting par-

117. For a general discussion of this dynamic, see my analysis in Janet Halley et al., From the International to the Local in Feminist Legal Responses: Four Studies in Contemporary Governance Feminism, 29 HaRv. J. L. \& Gender 336 (2006).

118. Janie Chuang, The United States as Global Sheriff: Unilateral Sanctions and Human Trafficking, 27 MICH. J. INT'L L. 437 (Winter 2006).

119. Robert $\mathrm{H}$. Mnookin \& Lewis Kornhauser, Bargaining in the Shadow of the Law: The Case of Divorce, 88 YALE L.J. 950 (1979).

120. Melvin A. Eisenberg, Private Ordering Through Negotiation: Dispute-Settlement and Rulemaking, 89 HARV. L. REv. 637 (1976).

121. See, e.g., Robert D. Cooter, Structural Adjudication and the New Law Merchant: A Model of Decentralized Law, 14 INT'L REv. L. \& Econ. 215 (1994); RoBert C. Ellickson, Order without Law: How Neighbors Setrle Disputes (1991).

122. Notable exceptions include Adelle Blackett, Promoting Domestic Workers' Human Dignity through Specific Regulation, in DOMESTIC WORK AS A FaCTOR OF EUrOPEAN IDENTITY: Understanding THE Globalization OF DOMEstic Work, 16TH-21ST CENTURIES 211 (Antoinette Fauve-Chamoux ed., 2005); Mundlak \& Shamir, supra note *; Ruthann Robson, A Servant of One's Own: The Continuing Class Struggle in Feminist Legal Theories, 23 Berkeley J. Gender L. \& Justice 392 (2008); Hila Shamir, The State of Care: Rethinking the Distributive Effects of Familial Care Policies in Liberal Welfare States, 58 AM. J. CoMP. L. 953 (2010). 
ties must be situated in relatively equal and interdependent bargaining positions. ${ }^{123}$

In general, such conditions do not exist here between employers and employees. The precariousness of the bargaining position of these workers is in part created by the lack of leverage stemming from the lack of legal protection in the form of foreground employment and labor regulations, as well as the insecurity of the right to work and very presence in the country informed by the background rules related to migration. As the discussion above demonstrates, one can identify several places within the legal system where a different rule choice and/or enforcement practice-e.g., a refusal of exceptionalism for domestic workers in the labor law code; better implementation of the right to work under international refugee law; stronger recognition of the human rights of migrant workers-would shore up the bargaining power of asylum seekers working as domestic laborers in Egypt. Without protection under international or domestic law, asylum seekers working in Egyptian households are bargaining not "in the shadow of law" but in its absence. This absence, however, is highly constructed by the law itself, in the form of "no-rights"124 rather than rights.

In this legally constructed zone of informality, "private ordering" is shaped most immediately by background social conditions, which generally range from indifference to hostility. Social service groups working with African refugee communities attest to extensive social marginalization, ranging from social segregation to verbal insults and physical harassment. ${ }^{125}$ Consequently, these communities in general are not able to secure educational opportunities or advancement in desirable jobs.

Beyond this social marginalization, the strong police presence of the authoritarian Egyptian government results in documented mistreatment of African migrant communities. ${ }^{126}$ "Round-ups of anyone who 'looks' African are often reported and unmistakably racially mo-

123. ElLICKSON,supra note 121

124. Wesley Hohfeld, Some Fundamental Legal Conceptions as Applied in Legal Reasoning, 23 YALE L.J. 28 (1913).

125. EIPR \& FIDH, supra note 66 , at 6 (observing that " $[\mathrm{m}]$ igrant workers, especially black Africans, report regular verbal harassment and physical attacks both in the streets by members of the public and by law-enforcement officials in Egypt" and detailing specific incidents). Social hostility results from both racial, see AHMED \& DIBB, supra note 40, at 25 (noting that the literature on Sudanese and other African refugees in Cairo "describe[s] racism as part of everyday life in Cairo and deem[s] racist attitudes . . . as institutionalized in areas such as healthcare and housing."), and economic biases, see Nkrumah, supra note 104 (quoting a source as saying, "Unemployment rates are very high in Egypt, and most Egyptians are poor and do not want Sudanese competition for limited job opportunities."). Many Egyptians would also protest that they have demonstrated relative hospitability towards these foreign and disadvantaged communities.

126. BADAWY, supra note 67 , at 4 . 
tivated."127 The 2005 police killings of Sudanese protesters constitute a particularly acute expression of this general environment.

Thus, the experience of African migrant workers in Cairo is one that is shaped, on the one hand, by gaping informality as channeled through historically and discursively constructed market preferences; and, on the other hand, by sporadic and hostile encounters with the state. The impact of exclusion, combined with these dynamics of bargaining, means a great deal of vulnerability. Women migrant domestic workers are "particularly vulnerable to discrimination, exploitation and abuse of all kinds, including harassment, violence by employers and coercion by employment agencies, forced labor, low wages and inadequate social coverage." 128 Labor abuses include not paying or withholding wages, not paying overtime, requiring long hours and difficult or heavy work, inadequate rest and leave, substandard living conditions, and lack of remedies for contract breach or termination. ${ }^{129}$ Because of their "isolated circumstances within private homes," the fact that they are "not protected by national labor law" and their migrant status, migrant domestic workers, predominantly women, are "at particular risk of forced labor."130

Within these generally bleak conditions, however, some variability does exist in employment relationships, and particular employers and employees can create their own scenarios that depart from the norm. ${ }^{131}$ In addition, some employers' preferences for particular nationalities (for example, Ethiopians are considered to be desirable

127. See EIPR \& FIDH, supra note 66 , at 7 . This report recounts the 2004 findings of UN Special Rapporteur on 2004 incident of racially motivated arrests of hundreds of foreigners that took place in Cairo:

During the raids, which reportedly took place on 28 and 29 January, plainclothes policemen and security forces allegedly entered homes, without showing either identification or warrants, and arrested foreigners, predominantly people of sub-Saharan African origin .... Still others were beaten during the arrests and sustained injuries as a result. It was reported that police wagons and minibuses patrolled the streets of the al-Maadi district of Cairo throughout the day on 28 January, looking for "Blacks." Reportedly, 28 January was referred to as "Black Day" and the intake sheet on which police took names at al-Maadi station was reportedly headed, in Arabic, "Operation Track Down Blacks." Detainees were reportedly held at al-Maadi and Bassatin police stations in inhumane and crowded conditions.

Id. (citing Report of the Special Rapporteur on the human rights of migrant workers, Gabriela Rodríguez Pizarro, Addendum: Communications sent to Governments and replies received, UN Doc. E/CN.4/2004/76/Add.1, para. 60).

128. International Labor Organization, Equality at Work: Tackling the Challenges 31 (2007).

129. Human Rights Watch, Swept under the Rug: Abuses Against Domestic WORKERS AROUND THE WORLD (2006).

130. ILO, supra note 128.

131. Interview with Dr. Ray Jureidini, Director of Center for Migration and Refugee Studies (CMRS), American University in Cairo, in Cairo, Egypt (Feb. 10, 2009). 
employees) lend those workers some bargaining power compared to their counterparts of other nationalities. ${ }^{132}$

Finally, some social networks can partially redress this gap by producing social pressures where there are community linkages amongst employers and/or employees. For example, where asylumseekers are placed by nonprofit groups, such as churches, with employers there may be a desire to maintain good standing in the eyes of the organization and any community associated with it. One church group in Egypt that places asylum seekers as domestic workers also creates simple, one-page contracts that set forth the agreed wage and hours. Church workers know that these contracts are completely unenforceable, but hope that the formalized act of creating them and the church "seal of approval" will increase the likelihood that the terms are followed.

There are limits to this dynamic, and it also can work in the opposite direction. In order to maintain placements for asylum seekers, the church is hesitant to be too demanding against employers. There is no language on termination in the contract; rather, if the employer fires someone, the church simply replaces the employee unless there is clear evidence of employer abuse. ${ }^{133}$ The foreground rules and background rules once again affect this situation: there is little normative pressure that could provide the basis for demanding better treatment.

\section{III: REFLECTIONS}

\section{A. Global Governance in a Context of Inequality and Instability}

This specific study of domestic workers' experiences in a politically complex region of the developing world speaks to the challenge of a highly specialized international law framework to govern a much more interpenetrated reality-one of the challenges identified in the International Law Commission's widely-read report on "fragmentation." ${ }^{134}$ As a de jure matter, several specialized international treaty

132. Interview with Mekonnen Firew, American University in Cairo, Egypt (Sept. 29,2008 ).

133. Interview with All Saints Cathedral, supra note 65.

134. See U.N. Int'l Law Comm'n, Fragmentation of International Law: Difficulties arising from the Diversification and Expansion of International Law, U.N. Doc. A/ CN.4/L.682 (Apr. 13, 2006) (finalized by Martti Koskenniemi) (“[S]uch specialized law-making and institution-building tends to take place with relative ignorance of legislative and institutional activities in the adjoining fields and of the general principles and practices of international law. The result is conflicts between rules or rulesystems, deviating institutional practices and, possibly, loss of an overall perspective on the law."); U.N. Int'l Law Comm'n, Fragmentation of International Law: Difficulties arising from the Diversification and Expansion of International Law, II 6, U.N. Doc. A/CN.4/L.702 (July 18, 2006) (finalized by Martti Koskenniemi) (defining fragmentation as "the emergence of specialized and (relatively) autonomous rules or rulecomplexes, legal institutions and spheres of legal practice."). 
bodies potentially address the plight of these workers: the UN Refugee Convention and the UN High Commissioner on Refugees; the UN Migrant Workers' Convention and the UN Rapporteur on Migrant Workers; and the ILO conventions on migrant workers. De facto, the reality is that migrants from the Sudan and the Horn of Africa are often seeking political asylum as well as economic survival, blurring and further complicating these already legally fragmented categories. The exclusion of domestic workers from the Egyptian national labor code is not untypical, and the lacuna created by this exclusion is not adequately supported by the ambiguous or inadequately implemented treaty provisions on the rights of refugees and/or migrant workers.

This study also provides occasion to consider the relationship between migration and sovereignty. Migration is often styled as a challenge to sovereignty and national identity, and sovereignty is deemed to include plenary power over immigration and citizenship rights. Yet modern-day state practices of immigration and border control are much more recent than either sovereignty or globalization. Prior to the late nineteenth century, no immigration law in the modern sense of the term existed, and migration in earlier waves of globalization was unchecked by such restrictions. Instead, such measures result from the bureaucratic capabilities and economic strategies of modern states. The need for economic expansion and the accompanying "problem of circulation" 135 led to governmental innovation of population control techniques with modern administrative technology. ${ }^{136}$ Governmental assertion of control over immigration may now therefore be interdependent with the rise of global liberalization in other sectors of the market. Economic globalization, then, does not solve the "problem of sovereignty" but rather renders it "more acute than ever."137

The interdependence of economic globalization and border control explains why migration flows have not been liberalized to any degree close to the extent that trade flows have under international law. Migration could, after all, be viewed as merely a subset of international trade, denoting flows of labor instead of goods or capital. Many economists argue that liberalizing migration flows would increase economic benefits and growth for poor countries many times over conventional trade liberalization. ${ }^{138}$ Instead, migration has remained a product largely of national law and policy. In fact, rather

135. Michel Foucault, Security, Territory, Population: Lectures at the ColLĖGE DE FRANCE, 1977-1978, at 12-13 (Graham Burchell trans., 2007).

136. Id. at 110 ("This state of government, which essentially bears on the population and calls upon and employs economic knowledge as an instrument, would correspond to a society controlled by apparatuses of security.").

137. Id. at 112 .

138. 2008 IOM Report, supra note 22 , at 41. 
than undergoing liberalization "[s]ince the early 1990s, prosperous Western states have been engaged in a worldwide crackdown on illegal migration."139

Particularly in a global context of deep inequality, citizenship in an affluent society is an extremely valuable asset. ${ }^{140}$ This affluence produces both the desirability of migration, for those in less well-off countries, and the fear that migration will erode it, in the affluent ones. Consequently, the current form of globalization often tends to situate the developing world as economically and politically problematic for rich countries. Migration into the developed world from developing countries has increased markedly over the past thirty years. ${ }^{141}$ Overall migration levels have remained stable over time, at about three percent altogether. ${ }^{142}$ However, in past eras migrating populations originated primarily in Europe ${ }^{143}$ and went to the western and southern hemispheres. While globalization itself is not new, ${ }^{144}$ its current form may be more visibly challenging the nationstates of the global North. Poor countries potentially threaten economic security of populations in the global North, either through the export of trade or the export of people. These influxes jeopardize the social and economic security that modern welfare states provided to offset the effects of earlier globalizations. ${ }^{145}$

This dynamic is by no means exclusive to the global North, as this Essay indicates. Indeed, in the wake of counterterrorism measures adopted by the West, a number of states elsewhere, including Egypt and some of its neighboring countries, ${ }^{146}$ have made

139. Dauvergne, supra note 72 , at 14 (2008).

140. Ayelet Shachar, The Birthright LotTery: Citizenship and Global IneQUALITY 5 (2009) ("full membership in an affluent society emerges as a complex form of property inheritance: a valuable entitlement that is transmitted, by law, to a restricted group of recipients under conditions that perpetuate the transfer of this precious entitlement .... This inheritance carries with it an immensely valuable bundle of rights, benefits and opportunities.").

141. 2008 IOM Report, supra note 22, at 33-34.

142. See Shachar, supra note 140 , at 5 .

143. 2008 IOM Report, supra note 22 , at 209.

144. Id. at 25 (describing three waves of globalization: (1) between 1870 and 1914-falling tariffs and transport costs allowed for export of intensive commodity production in "abundant" land [through colonialism] and also for significant emigration; (2) 1950-1980, manufacture trade liberalization through reduction in tariffs; (3) current: incorporation of developing countries as nation-states).

145. See Adelle Blackett, Trade Liberalization, Labour Law and Development: A Contextualization, ILO, Int'l Inst. for Labour Stud., Geneva, Discussion Paper DP/ 179/2007 (2007), available at http://www.ilo.org/public/english/bureau/inst/publications/discussion/dp17907.pdf (discussing Karl Polanyi's view that "social welfare entitlements for the paradigmatic workers in the North [were givenl in exchange for the progressive liberalization in the economy ....").

146. See Egyptian National Council for Human Rights, 2009 Annual Report (2009) (discussing the draft Egyptian counterterrorism law). For a discussion of similar proposed laws in Israel, see Mundlak, supra note 22, at 6 (discussing a new measure on "infiltration" which would provide "harsh measures for the detention and return of infiltrators" and establish that "they cannot be regularized."). For a discus- 
counterterrorism the justification for new and harsher laws and practices controlling migration. ${ }^{147}$ Such factors shape developing-country labor markets. While these labor markets are characterized by informality, workers' experiences are also punctuated by periodic and brutal encounters with the state in its punitive forms, e.g., in police round-ups, detentions and deportations. More recently, pressure from the global North has intervened to stem the tide of migration into the North from countries like Egypt, with the apparent effect of ramping up such police actions. Thus, the interaction of informality with biopolitics appears to form an important instantiation of the contemporary "developmental state."

\section{B. The Economic Family and Feminist Legal Theory}

One assumption of gender mainstreaming discourse is that women are in positions of greater social vulnerability because of historical subordination. ${ }^{148}$ In the market for domestic labor, however, historical constructs operate to give women a distinct socioeconomic advantage. Surveys by NGOs and academic researchers have found that migrant women are more able to find jobs because of the widespread availability of domestic work and the preference to hire women in that domain. In Cairo, pay for domestic work also tends to be higher than the jobs available to men from the same communities, which include serving as office cleaners, errand runners, and trash pickers. ${ }^{149}$ Migratory experience can simultaneously reinforce gender and race norms and inequalities at some levels, while challenging them at others by allowing women to become economic providers for themselves and for their transnational networks. ${ }^{150}$ The relative market advantage of women over men

sion of Libya's sudden and draconian border measures, see Interview with Mohamed Lotfy, supra note 99.

147. See Human Rights Watch, Israel: Court Should Halt Forced Returns of Migrants to Egypt, Avoid Complicity in Serious Egyptian Violations, Dec. 12, 2009.

148. This assumption about distributive justice is reflected in the "gender mainstreaming" discourse, defined by the UN Office of the Special Adviser on Gender Issues and Advancement of Women as "a globally accepted strategy for promoting gender equality ... [which] ensures that gender perspectives and attention to the goal of gender equality are central to all activities." U.N. Office of the Special Adviser on Gender Issues and Advancement of Women [OSAGI], Gender Mainstreaming, http:// www.un.org/womenwatch/osagi/gendermainstreaming.htm (last visited June 8, 2010).

149. Interview with All Saints Cathedral, supra note 65.

150. Jacqueline Bhabha has pointed out that this double-sidedness extends to legal recognition:

What the evidence reveals is that while female asylum seekers have a relative disadvantage in gaining access to developed states, but a relative advantage in securing asylum once they do gain access and an application is made, separated children appear, on the evidence available, to be in the opposite situation: relatively privileged in securing access, but disadvantaged in being accorded the security of refugee status. 
amongst African asylum seekers in Cairo may be seen as challenging, or at least qualifying, any assumption that gender relations always subordinate the former to the latter.

The significance of this market advantage should not be overstated. After all, it stems from employer preferences based on social profiles that reflect historical subordination. In addition to reinforcing disadvantageous social identity constructs, this market advantage does not necessarily reflect a great deal of material empowerment. The pay is still very low: African asylum-seekers "who are in Cairo (huge numbers, adverse living conditions, very limited resources), whose supposedly 'brief stay' in Egypt has taken many years, can barely manage their basic day-to-day needs."151 Moreover, the greater earning power of women over men can destabilize communities by reversing traditional hierarchies, a dynamic which, though certainly welcome from a broad perspective, may jeopardize survival strategies that depend on cohesiveness. ${ }^{152}$

At the least, however, feminist legal theory must take on board much more than it has to date the ramifications of structural differences among women on the basis of class, national origin, immigration status-and relationship to household labor. "Paid domestic labor poses real challenges on both a philosophical and a practical level to feminism." 153 In most cases, domestic workers are now hired by middle-class and elite women who are the wives and mothers of their household. Working women who hire other women do so to enable their own shift out of the household and into the market.

In the traditional patriarchal household, at least in the Western configuration of it, domestic laborers were required to create the basis for survival necessary to support the patriarch in political citizenship. A person toiling in the household could not be capable of full citizenship, because he or she was too tied to bare survival. ${ }^{154}$ Has the desire of middle- and upper-class women to eschew this zone of bare survival, of what Arendt called "animal labor," and to bid for full social citizenship, simply transferred that burden which is not only actual but also symbolic to the women that they employ? If so,

Demography and Rights: Women, Children and Access to Asylum, 16 INT'L J. REFUGEE L. 227, 238 (2004).

151. Assal, supra note 40 , at 7 .

152. Interview with Mulki Sharmani, Social Science Research Center, American University in Cairo (Feb. 10, 2009).

153. ANDERSON, supra note 16 , at 1 .

154. Hannah Arendt, The Human Condition 45 (2d ed. 1998) ("The private realm of the household was the sphere where the necessities of life, of individual survival as well as of continuity of the species, were taken care of and guaranteed .... [M] an existed in this sphere not as a truly human being but only as a specimen of the animal species man-kind."). 
women employers of domestic women workers may have taken on some aspects of the traditional patriarchal role. ${ }^{155}$

There are sharp implications here for gender policy and analysis. Whereas much feminist theory on the family focuses on the household wife/ mother, this social frame should be expanded to include the possible presence of women domestic workers. Within this frame, we should focus on the possible tensions between, and opposing interests of, women domestic migrant workers and women who are their employers. Indeed, women domestic workers are often wives and mothers themselves, who must find means of providing care work for their own households in their absence.

What results is a transnational and global "care chain," in which women with diverse social and legal status encounter each other through the negotiation of care work and other household labor. This diversity challenges some feminist constructs that have assumed a "homogeneity of oppression."156 Rather, the position of domestic workers is strongly affected by the legacy of particularized oppressions through colonialism and slavery, meaning that the relationship between women domestic workers and the women they work for may reproduce and reinforce some aspects of broader social hierarchies.

155. In an extensive study of domestic workers in Cairo households, sociologist Ray Jureidini reported that "[c]onsistent with other studies around the world, most [nonsexual abuse such as] yelling, name-calling and hitting was perpetrated by the 'madame' of the household." Jureidini, supra note 46 , at 87 .

156. ANDERSON, supra note 16 , at 5 . 